\title{
Normative data for semantically associated Spanish word lists that create false memories
}

\author{
JEFFREY S. ANASTASI and ALICIA DE LEON \\ Arizona State University West, Glendale, Arizona \\ and \\ MATTHEW G. RHODES \\ Washington University, St. Louis, Missouri
}

\begin{abstract}
The present study provides norms for Spanish word lists that have been used to create false memories in native speakers of Spanish. The word lists reported are based on the Roediger and McDermott (1995) lists that have been used extensively to examine illusory memories. We employed Roediger and McDermott's critical lures, translated them into Spanish, and created semantically associated Spanish word lists by testing native Spanish speakers. The resulting lists were then normed with additional native Spanish speakers. Overall, the participants recalled $53 \%$ of the list items and $32 \%$ of the critical lures with the word lists developed. In addition, $74 \%$ of the list items and $69 \%$ of the critical lures were recognized by the participants. The present study adds to the literature by providing a set of Spanish lists that can be used by researchers interested in evaluating false memories in individuals who speak Spanish. These norms may be downloaded from www.psychonomic.org/archive.
\end{abstract}

The Deese/Roediger-McDermott, or DRM, paradigm (Deese, 1959; Roediger \& McDermott, 1995) has reliably demonstrated that individuals can have compelling but false memories for words that were not presented. The typical procedure involves presenting participants with a list of words that are semantically related to a common theme word (i.e., the critical lure). At test, the participants frequently remember the critical lure despite the fact that it was never presented. For example, participants may be presented with a list of words related to the critical lure sleep, such as bed, rest, awake, dream, pillow, and so forth. When tested, the participants will often remember the critical lure sleep, despite the fact that sleep was never presented. This general finding has been replicated in a number of studies that have established that the false memory effect is quite robust (see, e.g., Anastasi, Rhodes, \& Burns, 2000; Gallo \& Roediger, 2001; Marsh, McDermott, \& Roediger, 2004; Norman \& Schacter, 1997; Payne, Elie, Blackwell, \& Neuschatz, 1996; Rhodes \& Anastasi, 2000; Seamon, Luo, \& Gallo, 1998).

With few exceptions, most studies in which false memories have been investigated with the DRM paradigm have made use of lists developed by Deese (1959), later revised by Roediger and McDermott (1995), and further expanded by Stadler, Roediger, and McDermott (1999). Roediger and McDermott initially took the six strongest lists from Deese

\footnotetext{
This work was partially supported by a Scholarship, Research, and Creative Activities (SRCA) grant from Arizona State University West. The authors thank Roberto Dell'Acqua and two anonymous reviewers for helpful comments on an earlier draft of the manuscript. Correspondence concerning this article should be sent to J. S. Anastasi, Department of Social and Behavioral Sciences, Arizona State University West, P.O. Box 37100, Phoenix, AZ 85069-7100 (e-mail: jeff.anastasi@asu.edu).
}

and demonstrated robust false recall and recognition that approximated list item memory. In their second experiment, they developed an additional 18 lists, providing a total of 24 lists. Once again, results revealed false recognition equal to veridical recognition and a level of false recall similar to that of list item recall. Stadler et al. conducted a norming study to investigate the strength of each of the lists developed by Roediger and McDermott, as well as 12 additional lists, using both recall and recognition tests. Stadler et al. showed that the different lists, although constructed in a similar manner, varied considerably in the probability with which the critical lure was falsely recalled or recognized. Such information is important for researchers investigating false memories with the DRM paradigm, since it provides crucial information concerning the probability that certain lists produce false memories.

To our knowledge, the DRM paradigm has been almost exclusively limited to English-speaking participants, with relatively few studies examining illusory memories in other languages (for exceptions, see Anastasi, Rhodes, Marquez, \& Velino, 2005; Pérez-Mata, Read, \& Diges, 2002; Zeelenberg \& Pecher, 2002; Zeelenberg, Plomp, \& Raaijmakers, 2003). Pérez-Mata et al. tested Spanish speakers in their second experiment, using associative Spanish lists. Zeelenberg and Pecher presented participants with items from the DRM lists that had been directly translated into Dutch. Anastasi et al. (2005) used a similar method in their Experiment 1 by directly translating six of the DRM lists into Spanish, Japanese, and German in order to test foreign exchange students in their native language. As was noted by Anastasi et al. (2005), one problem with this method is that the lists may have had greater associative strength in English, the language in which they were originally developed, than in the language into which 
they were translated. Specifically, the associative strength of the lists may have been weakened, since the associations inherent in the translated lists were based on norms from native English-speaking participants. Anastasi et al. (2005) corrected this problem in subsequent experiments by creating six new associative lists based on responses from native Spanish speakers, rather than using direct translations.

Although the production of these new lists by previous researchers (Anastasi et al., 2005; Pérez-Mata et al., 2002; Zeelenberg \& Pecher, 2002) is important, more lists need to be developed by collecting associative responses from native speakers, in order to preserve the associative nature of the lists. Furthermore, none of these previous studies provided normative data comparable to those reported by Stadler et al. (1999). Specifically, it is unclear which lists are more or less likely to produce false memories with recall and recognition tests, important information for researchers wishing to examine illusory memories with the DRM paradigm in other languages. In addition, PérezMata et al. evaluated only recall for the four lists that they developed, whereas Anastasi et al. (2005) and Zeelenberg and Pecher tested only participants' recognition memory for the lists that they developed. To our knowledge, no studies have tested both recall and recognition for the lists developed in other languages. There were several purposes for the present study. First, using the Spanish equivalent of the critical lures that were used by Roediger and McDermott (1995), we developed a set of 24 Spanish word lists for the present study with native Spanish speakers. Second, we presented each of these 24 lists to Spanish-speaking individuals and tested their memory, using both recall and recognition tests. Third, we present normative data for both list items and critical lures for each of the lists developed.

\section{METHOD}

\section{Participants}

There were a total of 88 participants in the present study, and all reported Mexico as their country of origin. Thirty-eight participants were used to create the Spanish lists. All of these 38 participants reported Spanish as their native language and reported fluency in Spanish. Their average age was 32.7 years $(S D=10.1)$, and these individuals reported having spoken Spanish for an average of 29.8 years $(S D=8.0)$. In addition, $84.2 \%$ of these individuals reported that Spanish was their primary language at home.

An additional 50 participants were used to norm the developed lists, using recall and recognition tests. All 50 participants reported Spanish as their native language. The average age of the participants was 31.5 years $(S D=11.8)$, with an average education level of 9.4 years $(S D=3.5)$. These participants reported using Spanish $98.4 \%$ of the time $(S D=4.2)$ at home, $87.3 \%$ of the time $(S D=22.4)$ at work, and $97.1 \%$ of the time $(S D=9.0)$ with friends. The participants were tested individually or in groups of up to 3 people.

\section{Materials}

The Spanish lists in the present study were constructed, using the same general format as that in Deese (1959) and Roediger and McDermott (1995), with 38 native Spanish speakers. PowerPoint was used to present the participants with the Spanish equivalent of the 24 Roediger and McDermott critical lures one at a time, and
Table 1

Mean Proportions of Critical Lures and List Items Recalled for Each Spanish List in the Present Study (With Standard Deviations) and for the English Lists Normed by Stadler, Roediger, and McDermott (1999)

\begin{tabular}{|c|c|c|c|c|c|c|}
\hline \multirow[b]{4}{*}{ List } & \multicolumn{4}{|c|}{ Present Study } & & \\
\hline & \multirow{2}{*}{\multicolumn{2}{|c|}{$\begin{array}{c}\text { Critical } \\
\text { Lures } \\
\end{array}$}} & \multirow{2}{*}{\multicolumn{2}{|c|}{$\begin{array}{c}\text { List } \\
\text { Items }\end{array}$}} & \multicolumn{2}{|c|}{ Stadler et al. (1999) } \\
\hline & & & & & \multirow{2}{*}{$\begin{array}{c}\text { Critical } \\
\text { Lures }\end{array}$} & \multirow{2}{*}{$\begin{array}{c}\text { List } \\
\text { Items }\end{array}$} \\
\hline & $M$ & $S D$ & $M$ & $S D$ & & \\
\hline Alto (high) & .68 & .47 & .48 & .12 & .26 & .58 \\
\hline Áspero (rough) & .64 & .48 & .45 & .14 & .53 & .56 \\
\hline Dulce (sweet) & .62 & .49 & .42 & .15 & .54 & .63 \\
\hline Frio (cold) & .52 & .50 & .60 & .10 & .44 & .61 \\
\hline Araña (spider) & .52 & .50 & .44 & .13 & .37 & .62 \\
\hline Dormir (sleep) & .50 & .53 & .64 & .14 & .61 & .61 \\
\hline Ventana (window) & .46 & .50 & .50 & .15 & .65 & .63 \\
\hline Silla (chair) & .44 & .50 & .58 & .11 & .54 & .64 \\
\hline Musica (music) & .38 & .49 & .55 & .12 & .34 & .59 \\
\hline Río (river) & .38 & .49 & .55 & .13 & .42 & .64 \\
\hline Niña (girl) & .30 & .46 & .50 & .13 & .32 & .67 \\
\hline Pie (foot) & .28 & .45 & .61 & .13 & .35 & .64 \\
\hline Aguja (needle) & .26 & .44 & .51 & .16 & .52 & .60 \\
\hline Ladrón (thief) & .24 & .43 & .51 & .12 & .23 & .61 \\
\hline Negro (black) & .22 & .42 & .47 & .14 & .34 & .60 \\
\hline Montaña (mountain) & .20 & .40 & .47 & .13 & .42 & .60 \\
\hline Enojo (anger) & .20 & .40 & .46 & .14 & .49 & .50 \\
\hline Hombre (man) & .18 & .39 & .56 & .14 & .24 & .56 \\
\hline Doctor (doctor) & .16 & .37 & .53 & .13 & .60 & .57 \\
\hline Pan (bread) & .16 & .37 & .52 & .14 & .31 & .55 \\
\hline Rey (king) & .12 & .33 & .61 & .14 & .10 & .65 \\
\hline Suave (soft) & .12 & .33 & .51 & .18 & .46 & .59 \\
\hline Fruta (fruit) & .06 & .24 & .68 & .13 & .20 & .71 \\
\hline Despacio (slow) & .00 & .00 & .59 & .16 & .42 & .53 \\
\hline Average & .30 & .12 & .53 & .07 & $.40(.14)$ & $.60(.05)$ \\
\hline
\end{tabular}

the participants were instructed to write down the first three words that came to mind on a provided answer sheet. All the instructions were given in Spanish. Each list used in the present experiment was then constructed from the 15 most frequent responses to each critical lure. The Spanish lists developed are provided in the Appendix, along with each item's approximate English translation. These lists were then presented to the second group of 50 participants in order to assess the likelihood that each list would produce false memories for the critical lure during recall and recognition testing. There were some words that had to be replaced by the next most frequent associate, due to replication in another list. When a substitution was necessary, the item was substituted from the list from which it had received fewer responses (i.e., the less frequent associate). For example, mujer was the 2nd most frequent associate for the hombre list and the 10th most frequent associate for the niña list. Therefore, the 16 th item (i.e., the 16th most frequent associate) was used to replace mujer on the niña list.

\section{Procedure}

The participants who were tested in order to norm the lists were instructed to view each word as it was presented on a computer screen for $2 \mathrm{sec}$ and were informed that their memory for these words would be tested later in the experiment. ${ }^{1}$ The participants then viewed the first 15-item list presented in blocked order of decreasing associative strength, using a PowerPoint presentation. All the items were presented in a 72-point font centered on the computer screen. Immediately following the study list presentation, the participants were given a recall test and were instructed to write down as many items from the list as possible. This was continued until the participants had received all 24 lists. After completing the final recall test, the participants were given a 144-item, paper-based yes/ 
no recognition test that contained 72 list items ( 3 from each of the 24 presented lists), 24 critical lures from the presented lists, and 48 nonlist items. The nonlist items were drawn from a pool of common Spanish words that were unrelated to the list items. All the instructions were given in Spanish.

\section{RESULTS}

\section{Recall Data}

List and critical lure recall data for each Spanish list are presented in Table 1. This table also provides the proportion of list items and critical lures recalled in the English lists normed by Stadler et al. (1999). Data from the Spanish lists showed great variability in the probability that the different lists would produce illusory memories. For example, despacio did not result in any critical lures being recalled, whereas alto led to more critical lures being recalled (.68) than list items (.48). Overall, the participants were more likely to recall list items $(M=.53, S D=.08)$ than critical lures $(M=.30, S D=.12)[t(49)=11.66$, $p<.01$; unless otherwise stated, the results are significant at $p<.05]$. The level of recall in the present study differs somewhat from that reported by Stadler et al., but the pattern is similar. For example, Stadler et al. found that a greater proportion of list items (.60) were recalled than critical lures (.40).

As in Stadler et al. (1999), the lists from the present study were split into the 12 lists most likely to lead to false memories and the 12 lists least likely to result in false memories. List recall was slightly higher for the bottom 12 lists $(M=.54, S D=.09)$ than for the top 12 lists $(M=$ $.52, S D=.08)[t(49)=2.27]$. However, not surprisingly, critical lure recall was much higher for the top 12 lists $(M=.47, S D=.21)$ then for to the bottom 12 lists $(M=$ $.16, S D=.14)[t(49)=8.92]$. Furthermore, the top 12 lists, on average, resulted in equivalent recall of list items and critical lures $[t(49)=1.45, p=.15]$, whereas list recall was significantly greater than critical lure recall for the bottom 12 lists $[t(49)=15.28]$. Stadler et al. reported a similar pattern of data, so that the top lists resulted in similar proportions of list items (.59) and critical lures (.51) recalled, whereas the bottom lists resulted in far greater list item (.62) than critical lure (.29) recall. ${ }^{2}$

\section{Recognition Data}

List item and critical lure recognition data for each Spanish list are presented in Table 2. This table also provides the proportion of list items and critical lures recognized in the English lists normed by Stadler et al. (1999). The recognition data also showed great variability between the different lists tested. For example, all the participants tested with the dormir list recognized the critical lure, whereas only $26 \%$ of the participants recognized the critical lure when given the negro list. Overall, the participants were significantly more likely to recognize list items $(M=.73, S D=.11)$ than critical lures $(M=.68$, $S D=.16)[t(49)=2.60]$. These data are consistent with those in Stadler et al., who reported that critical lures were falsely recognized $68 \%$ of the time, whereas list items were correctly recognized $70 \%$ of the time.
Table 2

Mean Proportions of Critical Lures and List Items Recognized for Each Spanish List in the Present Study (With Standard Deviations) and the English Lists Normed by Stadler, Roediger, and McDermott (1999)

\begin{tabular}{|c|c|c|c|c|c|c|}
\hline \multirow[b]{4}{*}{ List } & \multicolumn{4}{|c|}{ Present Study } & & \\
\hline & \multirow{2}{*}{\multicolumn{2}{|c|}{$\begin{array}{c}\text { Critical } \\
\text { Lures }\end{array}$}} & \multirow{2}{*}{\multicolumn{2}{|c|}{$\begin{array}{c}\text { List } \\
\text { Items }\end{array}$}} & \multicolumn{2}{|c|}{ Stadler et al. (1999) } \\
\hline & & & & & \multirow{2}{*}{$\begin{array}{l}\text { Critical } \\
\text { Lures }\end{array}$} & \multirow{2}{*}{$\begin{array}{c}\text { List } \\
\text { Items }\end{array}$} \\
\hline & $M$ & $S D$ & $M$ & $S D$ & & \\
\hline Dormir (sleep) & 1.00 & .00 & .90 & .16 & .80 & .73 \\
\hline Dulce (sweet) & .94 & .24 & .82 & .17 & .78 & .68 \\
\hline Alto (high) & .94 & .24 & .73 & .24 & .72 & .77 \\
\hline Ladrón (thief) & .94 & .24 & .67 & .26 & .70 & .71 \\
\hline Araña (spider) & .92 & .27 & .75 & .28 & .58 & .71 \\
\hline Fruta (fruit) & .84 & .37 & .89 & .18 & .45 & .86 \\
\hline Musica (music) & .82 & .39 & .76 & .26 & .69 & .59 \\
\hline Áspero (rough) & .78 & .42 & .63 & .32 & .83 & .71 \\
\hline Ventana (window) & .78 & .42 & .73 & .25 & .84 & .72 \\
\hline Pie (foot) & .76 & .43 & .74 & .25 & .62 & .59 \\
\hline Río (river) & .74 & .44 & .81 & .24 & .67 & .76 \\
\hline Frio (cold) & .72 & .45 & .85 & .22 & .84 & .79 \\
\hline Rey (king) & .72 & .45 & .77 & .22 & .27 & .69 \\
\hline Aguja (needle) & .70 & .46 & .91 & .18 & .68 & .71 \\
\hline Hombre (man) & .70 & .46 & .72 & .27 & .61 & .80 \\
\hline Niña (girl) & .70 & .46 & .71 & .28 & .58 & .88 \\
\hline Montaña (mountain) & .62 & .49 & .65 & .28 & .69 & .69 \\
\hline Suave (soft) & .54 & .50 & .73 & .33 & .81 & .63 \\
\hline Enojo (anger) & .54 & .50 & .51 & .38 & .79 & .69 \\
\hline Silla (chair) & .52 & .50 & .69 & .30 & .74 & .74 \\
\hline Doctor (doctor) & .44 & .50 & .65 & .30 & .71 & .68 \\
\hline Despacio (slow) & .36 & .48 & .76 & .25 & .69 & .56 \\
\hline Pan (bread) & .34 & .48 & .67 & .31 & .64 & .51 \\
\hline Negro (black) & .26 & .44 & .69 & .30 & .49 & .62 \\
\hline Average & .68 & .16 & .73 & .11 & $.68(.14)$ & $.70(.09)$ \\
\hline
\end{tabular}

As with the recall data, recognition data were also split into the top 12 and bottom 12 lists on the basis of the probability that the critical lure would be recognized. The participants recognized list items more often for the top 12 lists $(M=.77, S D=.10)$ than for the bottom 12 lists $(M=.70, S D=.14)[t(49)=5.24]$. Not surprisingly, critical lures were significantly more likely to be recognized for the top 12 lists $(M=.84, S D=.14)$ than for the bottom 12 lists $(M=.54, S D=.21)[t(49)=11.17]$. In addition, the top 12 lists, on average, resulted in more false memories than true memories $[t(49)=3.57]$, whereas the bottom 12 lists resulted in more true memories than false memories $[t(49)=6.06]$. Thus, the Spanish lists constructed in the present study adequately differentiated between those lists that were very likely to result in false recognition and those that did not. In addition, these data are similar to those of Stadler et al. (1999), who reported that their top lists resulted in $71 \%$ of list items and $77 \%$ of the critical lures being recognized, whereas their bottom lists resulted in $74 \%$ of list items and $55 \%$ of critical lures being recognized. ${ }^{3}$

\section{Correlational Data}

Pearson correlations were calculated for the mean proportion of list items and critical lures recalled and recognized by each participant. These data are listed in Table 3 and show that a significant correlation exists between list item recognition and critical lure recognition $(r=.51)$, 
indicating that veridical and false recognition accompany one another. The results also revealed a significant correlation between list item recall and list item recognition $(r=.34)$, since the participants tended to recall and recognize list items at similar levels. However, there was no correlation between list item and critical lure recall $(r=$ $.08, p=.57)$. In addition, there was no correlation between critical lure recall and critical lure recognition $(r=$ $.20, p=.15) .{ }^{4}$ Additional correlations were conducted to determine whether false recall and false recognition for the present Spanish norms were related to the English norms published by Stadler et al. (1999). These data revealed a moderate correlation between critical lure recall for the present norms and the Stadler et al. norms $(r=$ $.36, p=.09$ ). A similar analysis of critical lure recognition in which these norms were compared indicated that there was no significant correlation $(r=.12, p=.59)$.

\section{DISCUSSION}

In the present study, we created a unique set of Spanish associative lists, using native Spanish speakers. To our knowledge, no other study has developed associative lists using the DRM paradigm and provided normative data for both recall and recognition. Such normative data can be utilized by researchers interested in investigating illusory memories in Spanish speakers, using the DRM paradigm (Deese, 1959; Roediger \& McDermott, 1995). Another potentially important use of these lists is to conduct research investigating bilinguals, in order to help delineate the theoretical explanations for the false memory effect (see Anastasi et al., 2005). Furthermore, the present study provides a general method for converting the DRM lists into virtually any other language.

There are several key points to be taken from these data. First, the results demonstrate the robustness of the DRM false memory paradigm in other languages. As was noted previously, the normative data for the present Spanish lists are comparable to those for the English lists developed and normed by Stadler et al. (1999). Second, the effectiveness of the lists in producing false memories showed great variability, with some lists demonstrating very high levels of false recall or recognition, whereas other lists were much less likely to lead to false memories. For example, the alto list resulted in $68 \%$ of the participants recalling the critical lure, whereas the participants never recalled the critical lure for the despacio list. Dormir was the list most likely to result in false recognition $(M=$ 1.00 ), whereas the negro list was the least likely to lead to false recognition $(M=.26)$. Finally, we demonstrated a significant correlation between those lists that led to high levels of false recall and those that led to false recognition. Of course, there were some exceptions. For example, the fruta list was very effective in producing false recognition $(M=.84)$ but was one of the least effective lists for producing false recall $(M=.06)$.

The false memory effect has already gained the attention of many memory researchers, although the vast ma-
Table 3

Pearson Correlation Matrix for List Recall, List Recognition, Critical Lure (CL) Recall, and Critical Lure Recognition

\begin{tabular}{lcccc}
\hline & $\begin{array}{c}\text { List } \\
\text { Recall }\end{array}$ & $\begin{array}{c}\text { CL } \\
\text { Recall }\end{array}$ & $\begin{array}{c}\text { List } \\
\text { Recognition }\end{array}$ & $\begin{array}{c}\text { CL } \\
\text { Recognition }\end{array}$ \\
\hline List recall & 1.00 & & & \\
CL recall & .08 & 1.00 & & \\
List recognition & $.34^{*}$ & .05 & 1.00 & 1.00 \\
CL recognition & -.09 & .20 & $.51^{*}$ & \\
\hline
\end{tabular}

*Correlation significant at $p<.05$.

jority of studies have only tested English speakers using the DRM paradigm. The present study adds to the literature by providing a set of Spanish lists that can be used by researchers interested in testing individuals who speak Spanish. These norms are useful for researchers interested in assessing illusory memories with the DRM paradigm. We also provide and extend a useful methodology to develop and norm lists so that researchers can investigate this paradigm in virtually any language.

\section{REFERENCES}

Anastasi, J. S., Rhodes, M. G., \& Burns, M. C. (2000). Distinguishing between memory illusions and actual memories utilizing phenomenological measurements and explicit warnings. American Journal of Psychology, 113, 1-26.

Anastasi, J. S., Rhodes, M. G., Marquez, S., \& Velino, V. (2005). The incidence of false memories in native and non-native speakers. Memory, 13, 815-828.

DeEsE, J. (1959). On the predication of occurrence of particular verbal intrusions in immediate recall. Journal of Experimental Psychology, 58, 17-22.

Gallo, D. A., McDermott, K. B., Percer, J. M., \& Roediger, H. L., III (2001). Modality effects in false recall and false recognition. Journal of Experimental Psychology: Learning, Memory, \& Cognition, 27, 339-353.

Gallo, D. A., \& Roediger, H. L., III (2001). Variability among word lists in eliciting memory illusions: Evidence for activation and monitoring. Journal of Memory \& Language, 47, 469-497.

Marsh, R. L., McDermott, K. B., \& Roediger, H. L., III (2004). Does test-induced priming play a role in the creation of false memories? Memory, 12, 44-55.

Norman, K. A., \& Schacter, D. L. (1997). False recognition in younger and older adults: Exploring the characteristics of illusory memories. Memory \& Cognition, 25, 838-848.

Payne, D. G., Elie, C. J., Blackwell, J. M., \& Neuschatz, J. S. (1996). Memory illusions: Recalling, recognizing, and recollecting events that never occurred. Journal of Memory \& Language, 35, 261-285.

Pérez-Mata, M. N., Read, J. D., \& Diges, M. (2002). Effects of divided attention and word concreteness on correct recall and false memory reports. Memory, 10, 161-177.

Rhodes, M. G., \& AnAstasi, J. S. (2000). The effects of a levels-ofprocessing manipulation on false recall. Psychonomic Bulletin \& Review, 7, 158-162.

Roediger, H. L., III, \& McDermott, K. B. (1995). Creating false memories: Remembering words not presented in lists. Journal of Experimental Psychology: Learning, Memory, \& Cognition, 21, 803-814.

Seamon, J. G., Luo, C. R., \& Gallo, D. A. (1998). Creating false memories of words with or without recognition of list items: Evidence for nonconscious processes. Psychological Science, 9, 20-26.

Smith, R. E., \& Hunt, R. R. (1998). Presentation modality affects false memory. Psychonomic Bulletin \& Review, 5, 710-715.

Stadler, M. A., Roediger, H. L., III, \& McDermott, K. B. (1999). Norms for word lists that create false memories. Memory \& Cognition, 27, 494-500. 
Zeelenberg, R., \& Pecher, D. (2002). False memories and lexical decision: Even twelve primes do not cause long-term semantic priming. Acta Psychologica, 109, 269-284.

Zeelenberg, R., Plomp, G., \& Raaijmakers, J. G. W. (2003). Can false memories be created through nonconscious processes? Consciousness \& Cognition, 12, 403-412.

\section{ARCHIVED MATERIALS}

The following materials and links may be accessed through the Psychonomic Society's Norms, Stimuli, and Data archive, www.psychonomic .org/archive.

To access these files or links, search the archive for this article using the journal (Behavior Research Methods), the first author's name (Anastasi), and the publication year (2005).

FILE: Anastasi-BRMIC-2005.zip

DESCRIPTION: The compressed archive file contains two files:

Anastasi2005norms.xls, containing the Spanish norms developed by Anastasi, De Leon, and Rhodes (2005), as an 8K tab delimited text file generated by Microsoft Office Excel 2003 for the PC. The complete 15-item Spanish word lists are provided in alphabetical order based on the critical lure, with direct English translations in parentheses. The mean proportion of critical lures recalled and recognized for each Spanish list, with the standard deviation in parentheses, is also provided.

Anastasi2005aboutnorms.txt, containing a full description of the content of Anastasi2005norms.xls, including definitions of the items in the document (a $2 \mathrm{~K}$ plain text file).

AUTHOR's E-MAIL ADDREss: jeff.anastasi@asu.edu.

\section{NOTES}

1. It should be noted that previous studies have shown that the proportion of false memories reported is influenced by the modality of presentation. Specifically, researchers have demonstrated that presenting list items in an auditory modality results in an increase in false memories (Gallo, McDermott, Percer, \& Roediger, 2001; Smith \& Hunt, 1998), as compared with a visual mode of presentation. The present study utilized a visual presentation modality similar to that in Stadler, Roediger, and McDermott's (1999) norming study.

2. Overall, the participants in the present study were very unlikely to recall other nonlist items. The total number of other nonlist items recalled was $.76(S D=.24)$, or less than one nonlist item per list.

3 . The participants in the present study were very unlikely to recognize other, nonrelated distractors. Overall, the total proportion of other nonrelated distractors recognized was fairly low $(M=.25, S D=.15)$.

4. Pearson correlations were also calculated using the mean proportions of list items and critical lures recalled and recognized for each of the 24 lists by collapsing across participants. Examination of these data revealed a significant correlation between list item recall and list item recognition $(r=.52)$, indicating that, in general, the same lists tended to result in similar levels of recall and recognition of list items. A significant correlation was also evident between critical lure recall and critical lure recognition $(r=.59)$, since the same lists also tended to result in similar levels of both false recall and recognition. A significant correlation between list item and critical lure recognition $(r=.43)$ and a marginal correlation between list item and critical lure recall $(r=-.36, p=.08)$ revealed a relationship between both recall and recognition of list items and the likelihood that those lists would produce illusory memories.

\section{Normed Spanish Word Lists With the Direct English Translation in Parentheses}

$\begin{array}{lll}\text { Aguja (Needle) } & \text { Araña (Spider) } & \text { Despacio (Slow) } \\ \text { coser (to sew) } & \text { picadura (bite) } & \text { lento (slow) } \\ \text { hilo (thread) } & \text { telaraña (cobweb) } & \text { tortuga (tortoise) } \\ \text { ropa (clothing) } & \text { veneno (venom) } & \text { rápido (fast) } \\ \text { pica (stings) } & \text { peluda (hairy) } & \text { tiempo (time) } \\ \text { tela (fabric) } & \text { fea (ugly) } & \text { carro (car) } \\ \text { filosa (sharp) } & \text { animal (animal) } & \text { manejar (to drive) } \\ \text { metal (metal) } & \text { susto (scare) } & \text { vehículo (vehicle) } \\ \text { tejer (to web) } & \text { peligro (danger) } & \text { caracol (snail) } \\ \text { chico (small) } & \text { suciedad (filth) } & \text { tren (train) } \\ \text { máquina de coser (sewing machine) } & \text { patona (many legs) } & \text { viejo (old) } \\ \text { orificio (hole) } & \text { insecto (insect) } & \text { abuela (grandmother) } \\ \text { temor (fear) } & \text { fiera (wild beast) } & \text { burro (donkey) } \\ \text { dedal (thimble) } & \text { mata (kill) } & \text { mayores (elders) } \\ \text { vacuna (vaccine) } & \text { patas (legs) } & \text { aburrido (boring) } \\ \text { inyección (injection) } & \text { tarántula (tarantula) } & \text { reloj (clock) } \\ \text { Alto (High) } & \text { Áspero (Rough) } & \text { Doctor (Doctor) } \\ \text { edificio (building) } & \text { grueso (thick) } & \text { medicamentos (medicine) } \\ \text { parar (to raise) } & \text { rasposo (rough) } & \text { enfermo (sick) } \\ \text { delgado (thin) } & \text { tosco (coarse) } & \text { enfermedad (disease) } \\ \text { estatura (stature) } & \text { asfalto (asphalt) } & \text { hospital (hospital) } \\ \text { altura (height) } & \text { barba (beard) } & \text { dolor (pain) } \\ \text { automóvil (automobile) } & \text { grava (gravel) } & \text { alivio (relief) } \\ \text { cielo (sky) } & \text { lima (lime) } & \text { ayuda (help) } \\ \text { chaparro (short) } & \text { arena (sand) } & \text { sangre (blood) } \\ \text { nube (cloud) } & \text { ásperamente (roughness) } & \text { curar (to cure) } \\ \text { estrella (star) } & \text { fino (fine) } & \text { paciente (patient) } \\ \text { alcanzar (to reach) } & \text { granito (granite) } & \text { abrigo blanco (white coat) } \\ \text { arriba (above) } & \text { lijar (to sandpaper) } & \text { enfermera (nurse) } \\ \text { gigante (giant) } & \text { tocar (to touch) } & \text { salud (health) } \\ \text { medida (measure) } & \text { textura (texture) } & \text { chequeo (checkup) } \\ \text { largo (length) } & \text { duro (hard) } & \text { farmacia (pharmacy) } \\ & & \\ & & \\ \text { and } & & \end{array}$


APPENDIX (Continued)

\begin{tabular}{|c|c|c|}
\hline $\begin{array}{l}\text { Dormir (To Sleep) } \\
\text { sueño (dream) } \\
\text { cama (bed) } \\
\text { cansado (tired) } \\
\text { almohada (pillow) } \\
\text { cobija (blanket) } \\
\text { flojera (slack) } \\
\text { relajar (to relax) } \\
\text { pijama (pajamas) } \\
\text { roncar (to snore) } \\
\text { siesta (nap) } \\
\text { pesadillas (nightmares) } \\
\text { sábanas (sheets) } \\
\text { comfortable (comfortable) } \\
\text { recámara (bedroom) } \\
\text { acostarse (go to bed) }\end{array}$ & $\begin{array}{l}\text { Frio (Cold) } \\
\text { nieve (snow) } \\
\text { invierno (winter) } \\
\text { abrigo (overcoat) } \\
\text { hielo (ice) } \\
\text { caliente (hot) } \\
\text { aire (air) } \\
\text { suéter (sweater) } \\
\text { chamarra (jacket) } \\
\text { helado (frosty) } \\
\text { viento (wind) } \\
\text { lluvia (rain) } \\
\text { temblar (tremble) } \\
\text { Diciembre (December) } \\
\text { chimenea (fireplace) } \\
\text { resfriado (cold) }\end{array}$ & $\begin{array}{l}\text { Ladrón (Thief) } \\
\text { robar (to steal) } \\
\text { cárcel (jail) } \\
\text { policía (police) } \\
\text { pistola (handgun) } \\
\text { violencia (violence) } \\
\text { banco (bank) } \\
\text { acecho (to ambush) } \\
\text { desconfiar (to mistrust) } \\
\text { proscrito (bandit) } \\
\text { huir (to flee) } \\
\text { daño (damage) } \\
\text { mentiroso (liar) } \\
\text { máscara (mask) } \\
\text { ratero (pickpocket) } \\
\text { asalto (assault) }\end{array}$ \\
\hline $\begin{array}{l}\text { Dulce (Sweet) } \\
\text { chocolate (chocolate) } \\
\text { paleta (lollipop) } \\
\text { azúcar (sugar) } \\
\text { rico (rich) } \\
\text { amor (love) } \\
\text { soda (soda) } \\
\text { salado (salty) } \\
\text { sabroso (tasty) } \\
\text { miel (honey) } \\
\text { contento (content) } \\
\text { caramelo (candy) } \\
\text { bueno (good) } \\
\text { besos (kisses) } \\
\text { algodón de dulce (cotton candy) } \\
\text { agrio (sour) }\end{array}$ & $\begin{array}{l}\text { Fruta (Fruit) } \\
\text { manzana (apple) } \\
\text { naranja (orange) } \\
\text { plátano (banana) } \\
\text { piña (pineapple) } \\
\text { mango (mango) } \\
\text { uvas (grapes) } \\
\text { frescura (freshness) } \\
\text { fresas (strawberries) } \\
\text { saludable (healthy) } \\
\text { jugo (juice) } \\
\text { comer (to eat) } \\
\text { sandía (watermelon) } \\
\text { árbol (tree) } \\
\text { nutritivo (nutritious) } \\
\text { jugoso (juicy) }\end{array}$ & $\begin{array}{l}\text { Montaña (Mountain) } \\
\text { alta (high) } \\
\text { piedras (rocks) } \\
\text { subir (to rise) } \\
\text { grande (big) } \\
\text { verde (green) } \\
\text { volcán (volcano) } \\
\text { majestuoso (majestic) } \\
\text { sierra (mountain range) } \\
\text { bosque (forest) } \\
\text { palos (sticks) } \\
\text { calmada (calm) } \\
\text { ejercicio (exercise) } \\
\text { naturaleza (nature) } \\
\text { valle (valley) } \\
\text { tierra (land) }\end{array}$ \\
\hline $\begin{array}{l}\text { Enojo (Anger) } \\
\text { grito (shout) } \\
\text { frustración (frustration) } \\
\text { rojo (red) } \\
\text { molesto (annoying) } \\
\text { feo (ugly) } \\
\text { furioso (furious) } \\
\text { malo (bad) } \\
\text { ira (wrath) } \\
\text { corajes (anger) } \\
\text { emoción (emotion) } \\
\text { problemas (problems) } \\
\text { cansado (tired) } \\
\text { llorar (to cry) } \\
\text { ojos (eyes) } \\
\text { mentira (lie) }\end{array}$ & $\begin{array}{l}\text { Hombre (Man) } \\
\text { padre (father) } \\
\text { mujer (woman) } \\
\text { esposo (husband) } \\
\text { guapo (handsome) } \\
\text { señor (sir) } \\
\text { trabajador (hardworking) } \\
\text { fuerte (strong) } \\
\text { hermano (brother) } \\
\text { inteligente (intelligent) } \\
\text { abuelo (grandfather) } \\
\text { maduro (mature) } \\
\text { presidente (president) } \\
\text { macho (male) } \\
\text { tío (uncle) } \\
\text { masculino (masculine) }\end{array}$ & $\begin{array}{l}\text { Música (Music) } \\
\text { bailar (to dance) } \\
\text { baile (dance) } \\
\text { alegre (cheerful) } \\
\text { guitarra (guitar) } \\
\text { ritmo (rhythm) } \\
\text { fiesta (festival) } \\
\text { cantar (to sing) } \\
\text { violín (violin) } \\
\text { salsa (salsa) } \\
\text { alegría (joy) } \\
\text { Latina (Latin) } \\
\text { calma (calm) } \\
\text { clásico (classical) } \\
\text { rock (rock) } \\
\text { mariachi (mariachi) }\end{array}$ \\
\hline
\end{tabular}


APPENDIX (Continued)

\begin{tabular}{|c|c|c|}
\hline Negro (Black) & Pie (Foot) & Silla (Chair) \\
\hline oscuridad (obscurity) & zapato (shoe) & descanso (rest) \\
\hline gato (cat) & calcetín (sock) & sentarse (to sit) \\
\hline noche (night) & dedo (toe) & mesa (table) \\
\hline muerte (death) & uñas (toenails) & madera (wood) \\
\hline pelo (hair) & caminar (to walk) & cómodo (comfortable) \\
\hline elegante (elegant) & pierna (leg) & cocina (kitchen) \\
\hline miedo (fear) & tobillo (ankle) & mueble (furniture) \\
\hline color (color) & manos (hands) & cómoda (chest of drawers) \\
\hline cuervo (crow) & gordo (big) & comedor (dining room) \\
\hline color oscuro (dark color) & pata (paw) & café (brown) \\
\hline humo (smoke) & apestoso (smelly) & escalera (stairs) \\
\hline elegancia (elegance) & medias (stockings) & casa (house) \\
\hline persona (person) & sandalias (sandals) & sofá (sofa) \\
\hline tristeza (misery) & talón (heel) & sala (living room) \\
\hline funeral (funeral) & correr (to run) & carpintero (carpenter) \\
\hline Niña (Girl) & Rey (King) & Suave (Soft) \\
\hline bonita (pretty) & corona (crown) & piel (skin) \\
\hline vestido (dress) & reina (queen) & algodón (cotton) \\
\hline hija (daughter) & poder (power) & crema (cream) \\
\hline inocencia (innocence) & castillo (castle) & bebé (baby) \\
\hline niño (child) & dinero (money) & seda (silk) \\
\hline jovencita (youngster) & princesa (princess) & delicado (delicate) \\
\hline chiquita (small) & trono (throne) & terciopelo (velvet) \\
\hline trenzas (braids) & león (lion) & conejo (rabbit) \\
\hline muñecas (doll) & jefe (boss) & tierno (tender) \\
\hline escuela (school) & oro (gold) & flor (flower) \\
\hline juego (play) & copa (goblet) & cabello (hair) \\
\hline ternura (tenderness) & príncipe (prince) & gusta (like) \\
\hline señorita (young woman) & realeza (royalty) & caricia (caress) \\
\hline rosado (pink) & caballeros (knights) & sentir (to feel) \\
\hline hermana (sister) & doncella (maiden) & tela (cloth) \\
\hline Pan (Bread) & Río (River) & Ventana (Window) \\
\hline comida (food) & agua (water) & afuera (outside) \\
\hline leche (milk) & nadar (to swim) & quebrar (to break) \\
\hline delicioso (delicious) & corriente (current) & vidrio (glass) \\
\hline blanco (white) & campo (countryside) & claro (clear) \\
\hline mantequilla (butter) & fresco (fresh) & luz (light) \\
\hline blandito (soft) & pez (fish) & cortinas (curtains) \\
\hline hambre (hunger) & peligro (danger) & marco (frame) \\
\hline tostada (toast) & de Janeiro (De Janeiro) & cristal (crystal) \\
\hline pastel (cake) & limpia (clean) & ver (to see) \\
\hline comer (to eat) & arroyo (stream) & madera (wood) \\
\hline trigo (wheat) & rocas (rocks) & oportunidad (opportunity) \\
\hline loncha (slice) & azul (blue) & rayo de luz (ray of light) \\
\hline emparedado (sandwich) & salmón (salmon) & mirar (to look at) \\
\hline harina (flour) & canoa (canoe) & sol (sun) \\
\hline tortilla (tortilla) & barco (boat) & abierto (open) \\
\hline
\end{tabular}

(Manuscript received October 4, 2004;

revision accepted for publication November 26, 2004.) 